\title{
AN INQUIRY INTO THE EFFECTS OF MULTIPLE GRADED FACTORS ON STUDENT PERFORMANCE IN MANAGERIAL ACCOUNTING
}

\author{
Alexandra Ileana Muțiu ${ }^{1}$
}

\begin{abstract}
As many Managerial Accounting syllabi for live classes are built, the students' final grade is based on the following components: class participation, attendance, homework, mid-term exams and the final exam. We conducted a research in this Spring term for the Managerial Accounting course with two classes of 30 students each at the College of Business Administration, Plymouth State University, New Hampshire, USA. Our research results indicate that (1) class participation, attendance, and homework submission are factors that do not have significant effect on the students' examination grades and (2) the first midterm exam was significant as a tool to stimulate learning, in that it functioned as a "wake up" signal for the majority of the students analyzed. A major implication of this research suggests rethinking the structure of the final grade formula in the syllabus to further emphasize the elements that most directly increase students' motivation to learn.
\end{abstract}

Keywords: grade structure, mid term exams, participation in class, class attendance, accounting

JEL Codes: M49

Introduction

Determination of final grade's components is a sensitive issue that affects the quality of the learning process. Multiple paths could be followed in structuring the final grade, differences in between being attributed to culture, universities' practices, and professors' perceptions. Our experience as professors made us questioning if the components we were using in our work are interrelated or not.

The objective of the paper is to demonstrate the existence of a significant correlation between class attendance, class participation, homework submission and mid term exams on students' academic performance in an Accounting course in which the emphasis of the learning process is focused on students' individual work, as well as students' group work.

Therefore, in order to stimulate students to be more involved in class activities and of course, in the learning process, we decided to use the grading structure based on the above mentioned variables, as follows: class participation, attendance, homework submissions and both mid-term exams and final exam, an approach long used by accounting teachers at our research site, Plymouth State University in New Hampshire, USA. This approach is supported by the research done by Young and Shaw, who found that communication, positive learning atmosphere, concern for student learning, motivation, and organization are all predictors of teacher effectiveness (1999:674).

The innovative aspect of our research is brought by the fact that the empirical work regarding the impact of different grading policies on students' performance does not include applications to Accounting, a discipline for which student learning is directly tied to success in passing professional examinations (Elikai and Schuhmann, 2010:677).

\footnotetext{
${ }^{1}$ Babes-Bolyai University, Cluj Napoca, Romania, e-mail: alexandra13mutiu@yahoo.com
} 
The purpose of the research is to help us to understand better the influences of the several grading components on the final grade.

\section{Literature review}

In 2009, Matis et al. analyzed students' academic performance in correlation with their perception on Accounting, class attendance and perception on Power Point as an educational technology. Their study was conducted in Romania, for 156 sophomore students for the Financial Accounting class. Their study reveals that class attendance does not influence the students' academic performance. Considering this, they argue that attending the course does not help academic performance and believe that this is for sure an alarming aspect which requires action to be taken in order for the teaching process to reach its reason to be (Matis, 2009:289). Therefore, their suggestion is to develop educational technologies that focus more on students' individual study, without confining to ways of transmitting information through class teaching. (Matis, 2009: 290)

Furthermore, it has been suggested in the education literature that a grading system can also play an important role as a motivational tool to encourage students to exert greater effort toward their class work (Elikai and Schuhmann, 2010:689). In relation to the assessment process for student performance, other studies have shown that a higher frequency of exams represents one method that improves student performance in Accounting courses (Shoulders and Hicks, 2008:163). Murphy and Stanga (1994:39) found that having more frequent tests improved student performance on interim exams in an income tax course and improved student evaluations.

\section{Methodology}

The subjects of this study were 70 students at Plymouth State University in the United States, during a required Management Accounting course at the sophomore level, in the Spring of 2012. The students were taught in two separate sections of about 35 each. The discipline was studied during 15 weeks, each section having two weekly classes of one hour and forty minutes.

The final grade was structured according to the following model:

Course grade $=B 1($ Grade Exam 1) + B2 $($ Grade Exam 2$)+B 3($ Grade Exam 3$)+B 4($ No of HM submitted $)+B 5($ No of attendances $)+B 6($ No of class participation $)$

The proportions of each element in the course grade are:

$\begin{array}{lc}\text { B1: Grade Exam 1 } & 20 \% \\ \text { B2: Grade Exam 2 } & 20 \% \\ \text { B3: Grade Exam 3 (Final Exam) } & 20 \% \\ \text { B4: Homework submitted } & 15 \% \\ \text { B5: Attendance } & 10 \% \\ \text { B6: Class participation } & 15 \% \\ \text { TOTAL } & 100 \%\end{array}$

The same exams' structure was used for each exam: true and false questions, multiple choice questions, essays and problems. The first mid term exam (Exam 1) was scheduled in the seventh week of the term, the second exam (Exam 2) was scheduled in the thirteenth week of the term and the last one (Exam 3) in the exam period at the end of the term. The content of the discipline was divided proportionally among the exams.

Homework was assigned to students for each class. For $15 \%$ from the final grade, students were asked to submit the weekly homework via Moodle, an e-learning platform that Plymouth State University uses successfully, even for live classes. The purpose of this assignment was to stimulate 
the students' interest in solving the exercises assigned as homework and not the correctness of the solutions. Through this assignment we tried to motivate students to get involved in this course. Students were compensated for their efforts proportionally to the number of total assigned homework submitted.

We considered class attendance to be important in the learning process. The first prerequisite for learning in the classroom is to be there. So we graded class attendance in accordance, with a maximum percentage of 10 . An attendance list was completed for each class.

Beside simple attendance, we wanted students to be actively involved in the classroom activities. Hence, we allocated a percentage of 15 from the total grade to students who participate in class discussions, solving problems at the board, or offering constructive solutions or salient questions.

All this information regarding the grading scheme was made public on the Moodle site one week prior to the course's beginning. Therefore, students were informed timely about the course expectations and their way final grade would be determined.

Data needed for this study was collected during the term.

We analyzed all the elements that form the course grade. These components can be divided into two groups: exams' grades (for all three exams) and students' activity (reflected by homework submitted, attendance, and class participation). Since these activities and exams were run during the term, we were wondering and tried to observe if there is any correlation between these two groups. More specifically, we were considering the possibility of students' activities to influence the grade for exam 1,2 and 3.

Therefore, the hypothesis we try to validate is: Class participation, attendance, and homework submission are factors that do have a significant effect on the students' exams grades.

In order to demonstrate the validity of this hypothesis, we used the coefficient of determination technique, which is considered to be a more conservative measure of the relationship between the two variables than the correlation coefficient. It is preferred by statisticians and is seldom reported in research statistical data (Taylor, 1990:35). The coefficient of determination is defined as the percent of the variation in the values of the dependent variable $(y)$ that can be "explained" by variation in the value of the independent variable $(x)$ (Taylor, 1990:37). It is obtained by squaring the correlation coefficient $r$.

\section{Results}

The correlation coefficients are computed din Table 1 below. Based on it, Table 2 presents the coefficients of determination for all the elements that form the final grade.

\section{Correlation coefficients' matrix}

\begin{tabular}{crrrrrr}
\hline & $\begin{array}{c}\text { Grade } \\
\text { Exam 1 }\end{array}$ & $\begin{array}{c}\text { Grade } \\
\text { Exam 2 }\end{array}$ & $\begin{array}{c}\text { Grade } \\
\text { Exam 3 }\end{array}$ & $\begin{array}{c}\text { No of HM } \\
\text { submitted }\end{array}$ & $\begin{array}{c}\text { No of } \\
\text { attendances }\end{array}$ & $\begin{array}{c}\text { No of class } \\
\text { participation }\end{array}$ \\
\hline Grade Exam 1 & 1 & & & & & \\
Grade Exam 2 & 0.38 & 1 & & & & \\
Grade Exam 3 & 0.50 & 0.53 & 1 & & & \\
$\quad \begin{array}{c}\text { No of HM } \\
\text { submitted }\end{array}$ & 0.16 & 0.12 & 0.2 & 1 & & \\
No of attendances & 0.12 & 0.08 & 0.29 & 0.27 & & \\
$\quad \begin{array}{c}\text { No of class } \\
\text { participation }\end{array}$ & 0.30 & 0.00 & 0.29 & 0.40 & 0.30 & 1 \\
\hline
\end{tabular}


Matrix for the coefficients of determination

\begin{tabular}{cccc}
\hline y/x & $\begin{array}{c}\text { No of HM } \\
\text { submitted }\end{array}$ & $\begin{array}{c}\text { No of } \\
\text { attendances }\end{array}$ & $\begin{array}{c}\text { No of class } \\
\text { participation }\end{array}$ \\
\hline Grade Exam 1 & 0.03 & 0.01 & 0.09 \\
Grade Exam 2 & 0.01 & 0.00 & 0.00 \\
Grade Exam 3 & 0.04 & 0.08 & 0.07 \\
\hline
\end{tabular}

Table no. 2

Analyzing the first three items in Table: Grade Exam 1, Grade Exam 2 and Grade Exam 3, we observe high correlations between the following pairs:

- a correlation coefficient of 0.38 for Grade Exam 1 and 2,

- a correlation coefficient of 0.50 for Grade Exam 3 and 1 and,

- a correlation coefficient of 0.53 for Grade Exam 1 and 3.

Moreover, using descriptive statistics we computed the mean value for all the three exams, out of a maximum of 100. Their mean values are 68 for Exam 1, 81 for Exam 2 and 75 for Exam 3. These tell us that students received better grades at the second exam if compared with the first exam and the grade for the third one decreased slightly. After the second exam's grades were published, we've discussed the exam's results with students. Taking into account an increase of 12 points was registered between the first and the second exam, which, by the way, made the students very happy, we tried to investigate students on this issue. Therefore, after the second exam, we asked students their opinion by posing the following question: "In your opinion, what are the factors that contributed to this increase?" We asked this question of all the students present in that day in the class. The answers were anonymous. Most of the received answers referred to the fact that they had studied harder for the second exam than they did for the first one. Referring to the slight decrease of 6 points between the second and the last exam we didn't have the chance to investigate its cause. We could issue only suppositions, but we don't think this would be of any help.

Analyzing the second half of the Table 1 with respect to the exam grades, we notice that the correlation coefficients have a low value. We choose not to assert that there is a correlation between the analyzed variables. Still, the correlation coefficient of 0.44 between the number of submitted homework and number of class participation indicates to us that there is a tendency for those students who are actively involved in the class to submit the homework. Also, we observe that there is a weak correlation between number of class participations and number of attendances. Indeed, we remember that we had in the class about 25 students each time but we could count on just one hand those actively involved in discussions.

The figures in Table 2 indicate that only few percentages of the total variation in variables y: Grade Exam 1, 2 and 3 can be explained by a variation in variables $\mathrm{x}$ : number of homework submitted, number of attendance and number of class participation. As we can see from Table 2, less than $4 \%$ of the total variation of Grade Exam 1,2 and 3 can be explained by the variation in the number of submitted homework. Regarding the number of attendances, $8 \%$ from the total variation of Grade Exam 3 can be explained by this and almost zero percentage from the total variation for the first two exams. 9\%, respectively 7\% of the total variation in Grade Exam 1 and 3 can be explained by variation of the number of class participation. According to our data, the grade for the second exam is not influenced at all by the number of class participation.

The fact two variables: number of class participation and class attendance has such a small impact on the grades, makes us question: what is the reason that motivates students to come to classes? According to the presented results and our model used in structuring the course grade, the fact that they receive $10 \%$ from the grade because they are in the class is their motivation. 
Basically, for this Accounting for Managers class, we graded students partially for being in a specified place (the classroom), and not necessarily for acquiring new knowledge.

\section{Conclusions}

The analysis conducted suggests to us that students' activities during the term (homework submitted, class participation and attendance) have a weak influence in the students' learning process. Therefore, our hypothesis was not validated.

Also, we noticed that mid term exams represent a powerful factor that really contributes to students' learning. As a consequence, mid term exam should be used as an evaluation tool to stimulate the students' learning motivation. The results of the study show that the mid term exams are an efficient tool that functions like a "wake up" signal for the majority of the students analyzed. The results proved that the students' grades increased by an average of 10 points (on a 100 scale) from the first to the second mid term exam. Moreover, the results are backed up with the students' perception over their grades.

The results of the paper indicate us that we should reconsider our course structure. Looking back at the way the course grade is formed, we observe that $60 \%$ is represented by the exam (mid term exams and final exam) and $40 \%$ by students' activities. But, according to our results, students' activities don't influence the students grades received for exams. This structure of the final grade was based on our presumption that students' activities have a significant contribution on their grades. The results of this study show us the opposite. This leads to two potential solutions. First, we could eliminate the homework submitted, class participation and keep in our model the attendance along with the mid term grades. By following this approach, we still can stimulate students to interact with the class and the professor and therefore to improve their communications abilities. The second one would be to keep only the mid term grades as components of the final grade.

\section{References}

1. Elikai F., Schuhmann P. W., 2010. An Examination of the Impact of Grading Policies on Students'Achievement, Issues in Accounting Education. Vol. 25, N0. 4, 677-693

2. Matiş D., Mustață R. V., Bonaci C. G., 2009. Traditional versus modern approach in teaching accounting, 6th International Conference on Management of Techonological Cahnges, in Costache Rusu (Eds), Proceedings of 6th International Conference on Management of Techonological Cahnges, pp. 287-290

3. Murphy D.P., Stanga K. G., 1994. The effects of frequent testing in an income tax course: An experiment, Journal of Accounting Education 12 (1), 27-41

4. Shoulder C.D., Hicks S.A., 2008. ADEPT Learning Cycles Enhance Intermediate Accounting Students Learning Success, Issues in Accounting Education, Vol. 23, No. 2, 161-182

5. Taylor R., 1990. Interpretation of the Correlation Coefficient: A Basic Review, Journal of Diagnostic Medical Sonography, January/February, pp. 35-39

6. Young S., Shaw D. G., 1999. Profiles of effective college and university teachers, Journal of Higher Education 70, 671-686. 